DOI: https://doi.org/10.31933/dijemss.v2i6

Received: 23 August 2021, Revised: 15 September 2021, Publish: 30 September 2021

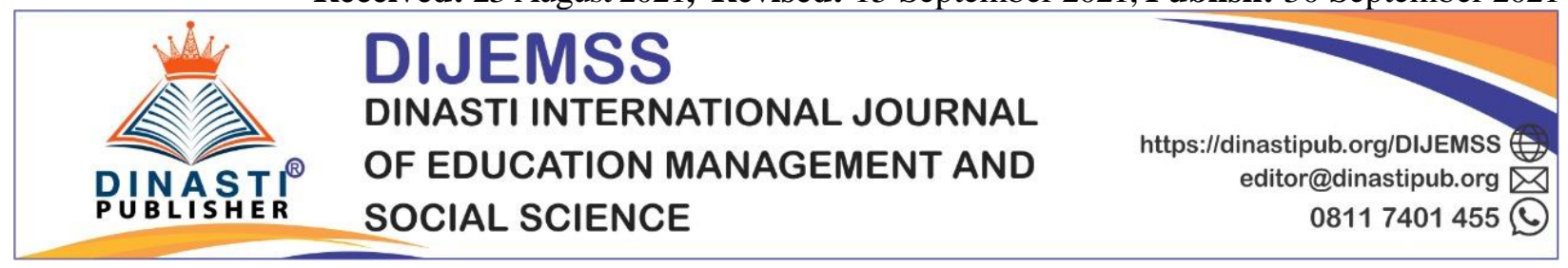

\title{
FACTORS AFFECTING TEACHER PERFORMANCE DURING THE COVID 19 ERA (MADRASAH IBTIDAIYAH CASE STUDY SOUTH JAKARTA)
}

\author{
Eva Fadhila Hanifa ${ }^{1}$, Aslam Mei Nur Widigdo ${ }^{2}$ \\ 1) Mercu Buana University, Jakarta,Indonesia, evafadhilahanifa@gmail.com \\ 2) Mercu Buana University, Jakarta, Indonesia, aslam.mei@mercubuana.ac.id
}

\section{Corresponding Author: Eva Fadhila Hanifa}

\begin{abstract}
The purpose of this study is to find out the factors that affecting teacher performance during the era of covid 19 (case study Madrasah Ibtidaiyah South Jakarta). The research method used is a quantitative approach with causal research. The research population is 96 teachers in Madrasah Ibtidaiyah Negeri, Jagakarsa Subdistrict, South Jakarta City. Sampling technique is nonprobability sampling with saturated sampling technique so that the sample number of 96 teachers. Research data is primary data obtained by distributing questionnaires. Quantitative data analysis methods use multiple linear regression methods. The analysis tool used is SPSS version 26.0. The results of the F test showed that competence, communication, creativity and work environment had a positive and significant influence on teacher performance. The results of the $t$ test on each variable showed that competence had no effect on teacher performance, communication had a significant and positive effect on teacher performance, creativity had a significant and positive effect on teacher performance and the work environment had no effect on teacher performance. Based on the results of the analysis, the performance of teachers during the covid 19 era can be maximized through the improvement of the creative process of creativity during the implementation of the learning process.
\end{abstract}

Keywords: Competence, Communication, Creativity, Work Environment, Teacher Performance, Covid 19

\section{INTRODUCTION}

Education occupies a very important position and becomes the main driver of a country's development. Education is a method of changing cultural values as a legacy from one generation to the next. Through quality education, of course, the human resources produced also have quality. Teachers become the most important part of education and its influence in printing quality human resources and in harmony with the purpose of education in Indonesia, because the need for human resources becomes an important thing for companies or organizations because in the absence of human resources, automated equipment, manuals and computerized ones cannot be operated and function properly (Mase and Widigdo, 2021). To achieve these goals, it takes teachers who have good performance in the learning process. 
Education in Indonesia today still faces some problems. The low quality of education affects quality human resources in Indonesia. Based on data published by UNESCO in the Global Education Monitoring (GEM) Report 2016, education in Indonesia is in the 10th position out of 14 developing countries. The teacher factor is ranked 14th out of 14 developing countries in the world. A report published by The United Nations Development Programme (UNDP) in 20152019 on the Human Development Index (HDI) or it can be said as the Human Development Index (HDI) showed that of the 189 countries surveyed, Indonesia occupied a low position. The HDI assessment covers three categories: health, education and income. One of the most important things in improving quality education in Indonesia is the improvement of teacher performance.

The lack of quality of education in Indonesia is caused by various obstacles. Bbased on presurvey research that is adapted to the current pandemic conditions, namely learning activities with sistem online (in network). The pre-survey was conducted by distributing questionnaires to 30 teachers in Madrasah Ibtidaiyah, South Jakarta, the main factors that led to teacher performance failing to be achieved were competence (93.33\%), communication (93.33\%), creativity $(86.66 \%)$ and work environment $(86.66 \%)$.

Table 1. Factors That Affect Teacher Performance

\begin{tabular}{|c|l|c|c|}
\hline No. & $\begin{array}{c}\text { Factors Affecting Teacher Performance } \\
\text { during the Covid 19 era }\end{array}$ & Frequency & Presentation \\
\hline 1 & Competence & $\mathbf{2 8}$ & $\mathbf{9 3 . 3 3 \%}$ \\
\hline 2 & Communication & $\mathbf{2 8}$ & $\mathbf{9 3 . 3 3 \%}$ \\
\hline 3 & Creativeness & $\mathbf{2 6}$ & $\mathbf{8 6 . 6 6 \%}$ \\
\hline 4 & Work Environment & $\mathbf{2 6}$ & $\mathbf{8 6 . 6 6 \%}$ \\
\hline 5 & Confidence & 24 & $80 \%$ \\
\hline 6 & Motivation & 24 & $80 \%$ \\
\hline 7 & Technology & 23 & $76.66 \%$ \\
\hline 8 & Management Program & 14 & $46.66 \%$ \\
\hline
\end{tabular}

Source: Questionnaire Data, processed (2021)

Based on the above background and pre-survey findings, the formulation of the problem is whether competence, communication, creativity and work environment affect teacher performance in Madrasah Ibtidaiyah, South Jakarta both partially and simultaneously? This research aims to find out and analyze the influence of competence, communication, creativity and work environment on teacher performance in Madrasah Ibtidaiyah, South Jakarta both partially and simultaneously.

\section{LITERATURE REVIEW}

In 2016 the Ministry of Education and Culture published data showing that teacher performance at the primary school level was second lowest compared to teacher performance at other levels of education, this was also supported by unsatisfactory UKG (Teacher Competency Test) results data. Related to the results of the UKG, Salim (2020) as Wasekjen of the Federation of Indonesian Teachers Union discussed the critical record of the Jakarta Teacher Competency Test, one of which was the attitude of the Jakarta Education Office which was closed about the results of UKG because it was worried about public / media criticism. The data that can still be 
seen by the public is data published by the Ministry of Education and Culture in 2015 with the average teacher score nationally for kindergarten teachers at 43.74 points, elementary teachers 40.14 points, junior high teachers 44.14 points and high school teachers 45.38 points. This value is below the Minimum Competency Standard (SKM) which is 55 (Kemendikbud). These results showed that elementary school teachers had the lowest points compared to other levels of education.

Teachers' performance scores vary due to many factors. Based on previous research, there are several factors that affect teacher performance with positive and significant results, including competence (Sari, Murtadlo, Basuki, 2019; Ibrohim, 2015; Giantoro, Haryadi and Purnomo, 2019; Rifqi, Machasin and Choiron, 2015), In addition, teacher competency standards have been established by Indonesian Law No. 14 of 2005 on teachers and lecturers (UUG) articles 8, 9 and 10 that teachers must have teacher competencies that include pedagogical competence, personality competence, social competence and professional competence.

Rifqi, Machasin and Choiron's research (2015) entitled Influence of Teacher Professional Competence, Self-Efficacy, and Interpersonal Communication against The Performance of Teachers SMPN 1 Kerinci Kanan Siak Regency resulted that teacher interpersonal communication has an effect on teacher performance. Sumiyati (2018) examined the relationship between creativity and the performance of high school chemistry teachers in Jabodetabek resulting in that creativity has a significant effect on teacher performance. Elfita, Zulhaini, and Mailani (2019) examined the Influence of the Work Environment on the Performance of Islamic Religious Education Teachers in MTs Negeri Sentajo Filial Singingi District Singingi Kuantan Singingi District resulted that the work environment in MTs Negeri Sentajo Filial Singingi has a significant influence on the performance of Islamic religious education teachers.

Previousresearch is done when normal conditions that show results have not been maximal on the performance of teachers. New conditions such as the covid 19 pandemic are forcing teachers to adapt immediately, work harder and remain at the forefront of the teaching and learning process, so it is necessary to change effective and efficientlearning methods. In this new condition will show maximum results on teacher performance with several factors that were previously researched and have an influence on teacher performance.

In the condition of the covid 19 pandemic, there are many schools that have been closed since March 16, 2020. Among the schools that apply work from home for teachers is Madrasah Ibtidaiyah Negeri located in Jagakarsa Subdistrict, South Jakarta City. This school dissolves all activities of the teaching and learning process in schools and is replaced with the process of teaching and learning at home to follow the government's appeal. This condition forces teachers to be able to improve performance with competence, communication, creativity, and can adapt to the new work environment.

Teacher performance according to Permendiknas Republik Indonesia No. 41 of 2007 regarding teacher activities in the learning process is how teachers prepare the learning process to make observations and assessments on students. Supardi (2016) presents three meanings of performance, namely ability, work results and achievements. It can be interpreted performance is the result of a behavior based on the ability to do responsibility.

Communication according to Nurudin (2016) an effort in conveying ideas to receive responses from ideas that have been conveyed. According to Firmansyah and Shamsudin (2016), communication is an activity of conveying and shouting information between two or more people 
using the right way, so that the intended message can be understood. Communication is the process of sending and receiving a message between two or more people with the processing of information or messages for a specific purpose.

Creative teachers will put more effort and work hard in finding appropriate methods in learning and teaching activities, so as to stimulate the students they teach to keep the spirit of learning whatever the conditions. Previous research by Lasalu (2015) mentioned that teacher creativity plays a role in improving student learning. Methods vary according to the material taught, able to present an active and pleasant learning state. This means that creativity is the development of ideas using the varied methods that teachers do during teaching and learning activities, because teacher creativity plays a role in improving student learning outcomes.

The work environment is one of the factors that affect the performance of teachers. In fact, there are still many schools that pay less attention to the work environment. Work environment is everything that is around the teacher and can affect the teacher during the learning process. According to Supiyata (2019) the work environment is a factor that has an impact on employee performance. A good work environment will bring a sense of security and allow employees to be as optimal as possible at work.

Based on previous research and a review of theories relating to competence, communication, creativity, and the work environment, the frame of mind for this research model can be seen as shown in picture 1 .

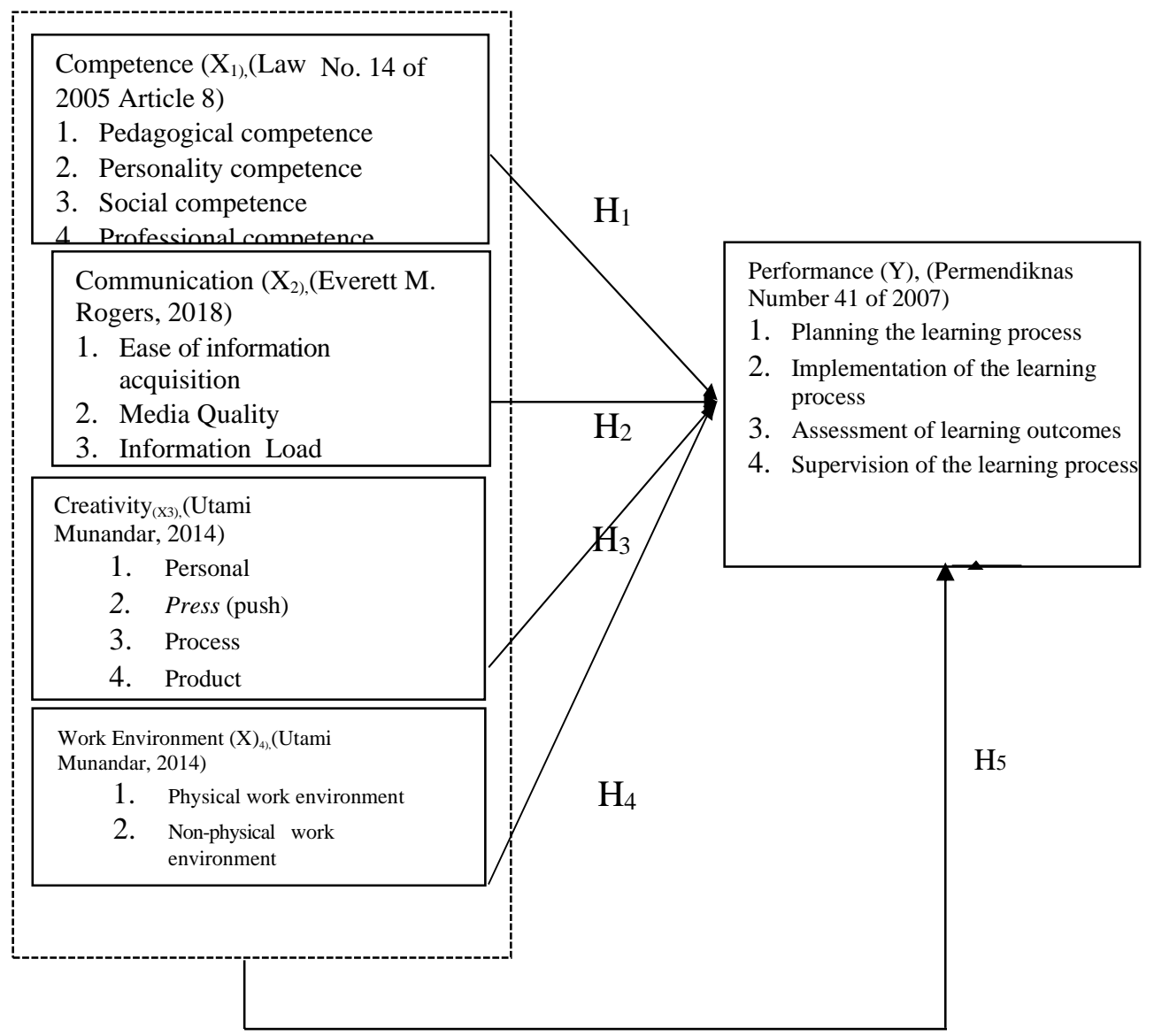


Figure 1. Framework of Thought

Research hypotheses that can be presented as follows:

1. Competence affects the performance of teachers.

2. Communication affects the performance of the teacher.

3. Creativity affects the performance of teachers.

4. The work environment affects the performance of teachers.

5. Kompetensi, communication, creativity and the environment of kerja influence simultaneously on the performance of teachers.

\section{RESEARCH METHODS}

The research method used is a quantitative approach with causal research. The study population was 96 teachers. Sampling technique is nonprobability sampling with saturated sampling technique so that the sample number of 96 teachers. Research data is primary data obtained by disseminating questionnaires and data sekunder. Once all the research data is collected it is then analyzed through multiple linear regression analysis with research instruments and hypothesis tests. The place of research is in Madrasah Ibtidaiyah Negeri, Jagakarsa Subdistrict, South Jakarta City. The time of his research on March 2 - 20, 2021.

\section{FINDINGS AND DISCUSSION}

\section{Research Result}

The results showed that $t$-calculated competency variables of -0.192 and Sig. $0.848>$ 0.05 ; $\mathrm{t}$ calculate the variable komunikasi of 2,454 and Sig. $0.001<0.05$; The t-count creativity variable is 5,186 withSig. $0.000<0.05$; and t-calculate the work environment variable is 1,294 with Sig. $0.199>0.05$,it can be concluded that the variable komptensi and work environment partially have no effect and communication and creativity variables partially have a positive influence and have a significant effect on the performance of madrasah teachers Ibtidaiyah,SouthJakarta,meaning $\mathrm{H} 1$ and $\mathrm{H} 4$ are rejected; $\mathrm{H} 2$ and $\mathrm{H} 3$ are accepted.

The regression equation resulting from the processing of such data is as follows: $\mathrm{Y}=6.744$ $-0.017 \mathrm{X} 1+0.097 \mathrm{X} 2+0.820 \mathrm{X} 3+0.098 \mathrm{X} 4$. The F and R2 test results showed that the F-count was 39,319 with Sig. $0.000<\mathrm{Tg}$. 0.05 , so it can be concluded that H5 which states that competence, communication, creativity and work environment simultaneously affect the performance of Madrasah Ibtidaiyah teachers, South Jakarta during the covid 19 era was accepted. Simultaneous influence was about $63.3 \%$, while the remaining $36.7 \%$ was determined by other factors outside ofthe study, such as organizational culture, organizational commitment, and work motivation.

Table 2 Results of Multiple Linear Regression Analysis

$\begin{array}{ll}\text { Unstandardized } & \text { Standardized } \\ \text { Coefficients } & \text { Coefficients }\end{array}$




\begin{tabular}{llllll}
\hline & B & $\begin{array}{l}\text { Std. } \\
\text { Eype }\end{array}$ & Beta & t & Sig. \\
\hline 1 (constant) & 6,744 & 3,443 & & 1,959 & 0,053 \\
\hline Competence & $-0,017$ & 0,091 & $-0,016$ & $-0,192$ & 0,848 \\
\hline Communication & 0,097 & 0,214 & 0,058 & 2,454 & 0,001 \\
\hline Creativeness & 0,820 & 0,158 & 0,696 & 5,186 & 0,000 \\
\hline Work Environment & 0,098 & 0,076 & 0,100 & 1,294 & 0.199 \\
\hline Anova (Fhitung) & & & $\mathbf{3 9 , 3 1 9}$ & $\mathbf{. 0 0 0}^{\mathbf{b}}$ \\
\hline R(multiple regression) & & & 0,633 \\
\hline Adjusted R Square & & & & $\mathbf{6 1 7}$ \\
\hline
\end{tabular}

Source: Questionnaire Data, processed (2021)

\section{Inter-Dimensional Correlation}

Based on the results of the correlation matrix analysis test between dimensions in table 4.21 it can be seen that competency variables have the closest inter-dimensional relationship in the social dimension with teacher performance variables in the learning process implementation dimension of 0.562 (moderate correlation). While the competency variable in the personality dimension has no correlation with the teacher performance variable in the dimension of supervision of the learning process because the calculation $r$ is smaller than the table of 0.202.

Communication variables have a dimension of ease of obtaining information that relates strongly to teacher performance variables in the dimension of the implementation of the learning process 0.679 (strong correlation) and for the weakest communication variable in the dimension of information content with teacher performance variables are in the dimension of supervision of the learning process because the value of $r$ calculates smaller than the table $r$ which is 0.202.

The creativity variable in the creative process dimension with the teacher performance variable in the learning process implementation dimension has a strong relationship of 0.744 (strong correlation). But in the creativity variable in the press dimension (push) with the teacher performance variable in the dimension of supervision of the learning process does not have a significant correlation because the calculated $r$ value of 0.146 is smaller than the table $\mathrm{r} 0.202$. Furthermore, the work environment variable has a non-physical work environment dimension that is strongly related to the teacher performance variable in the dimension of the implementation of the learning process and for the weakest work environment variable in the dimension of the physical work environment with the teacher performance variable is in the dimension of supervision of the learning process because the value of $r$ calculates more than 0.098 smaller than the table $r$ which is 0.202 .

Table3. Correlation Results Between Dimensions

\begin{tabular}{|c|c|c|c|c|c|}
\hline \multirow[b]{2}{*}{ Variable } & \multirow[b]{2}{*}{ Dimension } & \multicolumn{4}{|c|}{ Teacher Performance } \\
\hline & & 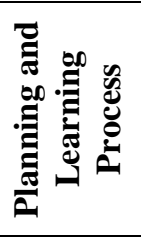 & 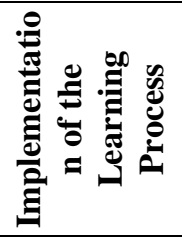 & 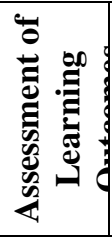 & 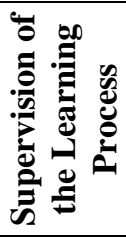 \\
\hline \multirow{3}{*}{ Competence } & Pedagogical & 0,397 & 0,38 & 0,179 & 0,117 \\
\hline & Personality & 0,245 & 0,259 & 0,185 & $-0,036$ \\
\hline & Social & 0,409 & 0,562 & 0,406 & 0,111 \\
\hline
\end{tabular}




\begin{tabular}{|c|l|c|c|c|c|} 
& Professional & 0,411 & 0,454 & 0,343 & 0,384 \\
\hline \multirow{4}{*}{ Communication } & Ease of Information Acquisition & 0,639 & $\mathbf{0 , 6 7 9}$ & 0,531 & 0,324 \\
\cline { 2 - 6 } & Media Quality & 0,441 & 0,573 & 0,514 & 0,154 \\
\cline { 2 - 6 } & Information Load & 0,405 & 0,565 & 0,471 & 0,113 \\
\hline \multirow{4}{*}{ Creativeness } & Personal & 0,577 & 0,553 & 0,462 & 0,174 \\
\cline { 2 - 6 } & Press (push) & 0,633 & 0,672 & 0,610 & $\mathbf{0 , 1 4 6}$ \\
\cline { 2 - 6 } & Creative Process & 0,648 & $\mathbf{0 , 7 4 4}$ & 0,471 & 0,329 \\
\cline { 2 - 6 } & Creative Products & 0,654 & 0,646 & 0,567 & 0,264 \\
\hline \multirow{2}{*}{$\begin{array}{c}\text { Work } \\
\text { Environment }\end{array}$} & Physical Work Environment & 0,344 & 0,385 & 0,330 & $\mathbf{0 , 0 9 8}$ \\
\cline { 2 - 6 } & Non-Physical Work Environment & $\mathbf{0 , 6 8 0}$ & 0,701 & 0,637 & 0,217 \\
\hline
\end{tabular}

Source: Questionnaire Data, processed (2021)

\section{Discussion}

Based on the results of the hypothesis test on competency variables have a $<$ ttabel result of $-0.192<1,990$ can be stated competency variables have no significant and negative influence on teacher performance during the covid 19 era. Based on data showing that the teacher has understood the competence that is in him, it's just that this competency can not be applied during the covid 19 era, conditions that are different from normal conditions in general. Competence becomes important when normal conditions, but during pandemic times there are other factors that are more important because it has a greater influence on teacher performance during this pandemic.

Tutu, A. (2012) in his research mentioned that competence has no effect on performance and Susanti (2016) found that teacher competence slightly affects hisperformance, teacher ompetensi is not so significant in improving performance and kompetensi teachers consist ofinsights, such as mastery of teaching materials, teaching experience and expertise. There is an accordance with the results of previous research that states that competency variables have no influence on teacher performance. Teachers already understand about competence and carry out their duties well so that the application during the covid 19 era has no influence on performance that is different from the application when normal or face-to-face conditions and there are other factors that affect the performance of teachers during the covid 19 era.

The results of the hypothesis test on communication variables have a $>$ ttabel result of 2,454 > 1,990 these results mean communication has a significant and productive influence on teacher performance during the covid 19 era. Based on correlation between dimensions, the ease of obtaining information is the highest cause of increasing the implementation of the learning process. The results of the study are in accordance with Bruner's theory (Rusmono 2014, p. 14) states that learning is a cognitive process that occurs in a person. Therefore there are three cognitive processes that occur in learning, namely: 1) The process of obtaining new information; 2) The process of transforming the information received; and 3) Test the relevance and accuracy of knowledge.

Themainthing in this case is the ability of teachers in communicating one of them easily obtains information, especially in this pandemic period can facilitate the implementation of the online learning process. So based on the results of research can be 
said if the ease of information acquisition is getting better, it has a significant influence on teacher performance during the covid 19 era. In this study in line with the research of Rifqi, Machasin and Choiron (2015) in their research, the interpersonal communication of teachers has an influence on teacher performance during the covid 19 era.

So that it can be concluded on communication variables in line with previous research, namely the existence of significant influences and in line with the definition of experts. Based on this study, teachers can further optimize communication with the principal and his or herstaff, students,fellow teachers and parents of students in pandemic times such as today because communication has an influence on teacher performance and communication is connected to each other with high intensity through communication tools and other media that have a high risk of lack or loss of perception in receiving information.

The results of the hypothesis test on the creativity variable had a $>$ ttabel result of $5,186>1,990$, these results showed creativity had a significant and positive influence on teacher performance during the covid 19 era. Based on the correlation between dimensions, the creative process is the highest cause of increasing the implementation of the learning process. The results of the study in accordance with the theory of Siregar and Nara (Theory of Learning and Learning 2010, h. 98) suggest that the creativity of a learning is the emphasis of learning on how teachers can facilitate learning activities, so that the learning atmosphere becomes conducive andcomfortable, this requires educators to pack learning materials, so that learning citizens can also be stimulated when doing creative and fun activities.

The main thingis the creativity of teachers in teaching and working from home, one of which is by constantly updating their ability both in using applications, communication tools and other media used in the learning process. Teachers are forced to be able to develop good ideas in making material, delivering material and in conducting assessments and evaluations, because teaching and learning activities in networking require more creativity compared to the learning process with face-to-face methods. The online learning process has the risk of saturation that can be felt by teachers and students. Based on the results of this study it can be said that if the creative process is getting better, it will have a significant impact on teacher performance during the covid 19 era. This research has the same results as Sumiyati (2018) in his research mentioning creativity has an influence and significant on teacher performance during the covid 19 era.

The hypothesis test results on work environment variables were 1,294<1,990, results that showed the work environment had no significant and positive effect on teacher performance during the covid 19 era. In the results of correlation between dimensions that show that the dimensions of the non-physical work environment have the greatest relationship with the dimensions of the implementation of the learning process. This study has the same results as Arianto's research (2013) showing the work environment does not affect teacher performance during the covid 19 era, because interactions or meetings between colleagues and students are limited, although they cannot meet face-to-face, teachers can still interact virtually so that the work environment has no effect on teacher performance during the covid 19 era, because it does not hamper teacher activity both while working and when socializing with $\mathrm{n}$. 
Based on the influence of competence, communication, creativity and work environment on teacher performance during the covid 19 era and the results of ujiF stated that the factors of competence, communication, creativity and work environment have a collective influence on teacher performance during the covid 19 era. It can be concluded that competence, communication, creativity and work environment together have an influence on teacher performance during the covid 19 era. Therefore, the research model can be used by educational institutions with the following overall factors, namely competence, communication, creativity and the work environment has an influence on teacher performance during the covid 19 era. So that educational institutions can further optimize the four aspects, namely competence, communication and creativity in the form of training or seminars and other education to be able to provide stimulus to educators and the work environment either in the form of the maintenance of work tools or the addition of work facilities to be able to provide significant improvement in employee performance.

\section{CONCLUSION, MANAGERIAL IMPLICATION, AND RECOMMENDATION Conclusion}

Based on the research that has been anointed the conclusions include:

1. Competence has no influence on teacher performance during the covid 19 era. Competence becomes important when normal conditions, but during the covid 19 pandemic there are other factors that are more important because it has a greater influence on teacher performance.

2. Communication has a positive and significant influence on teacher performance during the Covid 19 era. This means that the better the communication ability in a teacher, the better the teacher's performance will increase. Ease of information acquisition becomes the dimension that most affects the increase or decrease in teacher performance.

3. Creativity has a positive and significant influence on teacher performance during the covid 19 era, this means the better creativity in a teacher, the better the teacher's performance will increase. Press (encouragement) becomes the dimension that most influences the increase or decrease in teacher performance.

4. The work environment has no influence on teacher performance during the Covid 19 era. It can be concluded that teachers will continue to carry out their responsibilities despite being in a different environment from the school, because the conditions of the covid 19 pandemic force teachers to be able to continue to carry out their responsibilities.

5. Competence, communication, creativity and the work environment simultaneously have an influence on teacher performance during the covid 19 era. This shows that this predictor factor is able to improve teacher performance during the Covid 19 era.

\section{Managerial Implication}

Based on the results of this study, the managerial implications that can be conveyed and suggested are: 
1. The Ministry of Education and the Ministry of Religious Affairs can pay more attention to teachers in dealing with the conditions of the covid 19 pandemic by providing socialization and training on the importance of implementing competence during work from home in the covid 19 era and providing support so that teachers can apply competencies that have been understood to be applicable whatever the circumstances/conditions that are happening.

2. Support from the school in providing training and seminars to provide stimulus to teachers to continue to develop the ability to communicate both in small and largescopes.

3. Kepala school can provide motivation for teachers to grow and increase the spirit of work to excel and be more creative in work. To get teachers who have creativity in carrying out their duties, the principal has a role by trusting teachers, delegitimizing duties and authorities, having concern and empathy for teachers, and building a vision by involving teachers, and being a bridge for teachers with the Ministry of Education and the Ministry of Religion in meeting the needs or facilities of teachers in teaching specifically in the covid 19 era.

4. The willingness of teachers to be able to continue to develop insights and update their ability to work so as to improve the quality of performance and adapt easily in the face of every circumstance and every change.

\section{Suggestions}

Here are the suggestions submitted based on the results of this study:

1. Communication can affect teacher performance during work from home in the covid 19 era. Based on the data, the ease of obtaining information has the highest influence in the implementation of the learning process. This shows that the quantity and quality of communication is very necessary, so it takes the cooperation of all involved in this communication circle to maintain if it is good and improve the quality in order to create good communication and lancer and if there are difficulties during the Covid 19 era can be overcome together.

2. Creativity has a great influence on teacher performance during work from home in the covid 19 era. Based on data, the creative process has a huge influence on the implementation of the learning process. This shows that teachers are required to continue to develop ideas, both in preparing learning, when online learning takes place and after learning takes place. In addition, the school also has a role in fostering teacher creativity during work from home.

\section{BIBLIOGRAPHY}

Arianto, D.A.N. 2013. "TheInfluence of Discipline, Work Environment and Work Culture on The Performance of Teachers". Journal of Economia. Vol. 9 (2), pp:191-200.

Daryanto. 2013. Effective Learning Innovation. Yrama Widya: Bandung.

Elfita, R., Zulhaini, and Mailani, I. 2019. "TheInfluence of the Work Environment on the Performance of Islamic Education Teachers in MTs Negeri Sentajo Filial Singingi 
District Singingi Kuantan Singingi Regency". Journal of Al-Hikmah. Vol. 1 (1), pp: 40 -41 .

Firmansyah, Hilman, and Shamsudin, A. 2016. "Organizationand Business Management". Waves: Yogyakarta.

Giantoro, H.M., Haryadi, H., and Purnomo, R. 2019. "Influenceof Teacher Competence, Headmaster Leadership according to Teacher Perception and Work Motivation on The Performance of State Vocational Teachers in Purbalingga Regency". Economics, Business, and Accountantsi. Vol. 21 (2), pp: $1-11$

Global Education Monitoring Report Team (GEM Report). 2016. [Online] Available: https://en.unesco.org/ [November 29 2020].

Ministry of Education andCulture Data center and Statistics of Education and Culture. 2016. Human Resources primary and secondary education. Jakarta.

Mase, D.J.E.P and Widigdo, A.M.N. 2021. "Influenceof Organizational Culture, Leadership, Compensation and Training on Employee Engagement at BPJS Health Headquarters". Journal of Economics Management of Information Systems. VOL. 2 (4), pp: 447.

Nurudin. 2016. Scientific and Popular Communication Sciences. PT. King Grafindo Persada: Jakarta.

Permendiknas RI No. 41 of 2007 concerning TheStandard Processfor Elementary Education Unit dan Menengah.

Purba, C.B., Rafiani, Ali, H., 2018. "TheInfluence of Competency, Organizational Commitment and Non Financial Compensation on Teacher Performance in SMAN 29 Jakarta". Scholars Journal of Economics, Business and Management (SJEBM).

Ridho, M.H. 2016. Professional Competence of Fiqh Subject Teacher in Class VII MTS Darul Hikmah Tawangsari, Skripsi. Tulungagung: Tulungagung State Islamic Institute.

Rifqi, A., Machasin and Choiron, A. 2015. Influence of Teacher Professional Competence, Self-Efficacy, and Interpersonal Communication on The Performance of SMPN 1 Teacher Kerinci Kanan Siak Regency. Online Journal of Students of the Faculty of Economics, University of Riau.

Riyanto, Y. 2010. New Paradigm of Learning. Prenada Media Group: Jakarta.

Ruslan, S. 2016. Basic Concepts of PerformanceManagement. Mercu BuanaUniversity: Jakarta.

Rusmono. 2014. Learning Strategies with Problem Based Learning That Is Necessary. Ghalia Indonesia: Bogor.

Sari, P.H., Murtadlo and Basuki, I. 2019. "TheInfluence of Competence, Work Motivation and Incentives on high schoolteacherperformance" Educational Perspective. VOL. 33 (1), pp: $69-78$.

Siregar, E and Nara, H. 2010. Theory of Learning and Learning. Ghalia Indonesia: Bogor. 
Sondakh, R., Boham, A. and Harilama, S.H. 2017. "TeacherCommunication Patterns in The Learning Process of Down Syndrome Children at Malalayang Disability Children's EducationFoundation". E-Journal Acta Diurna. VOL. VI (1),pp: 1 - 15.

Sugiyono. 2018. Quantitative, Qualitative, and R\&D Research Methods. Alphabet: Bandung.

Sumiyati. 2018. "TheRelationship Between Creativity and The Performance of High School Chemistry Teachers at JABODETABEK". Journal of Educational Dynamics. VOL. 11 (1), pp: $58-80$.

Supardi, D. 2016. Teacher performance. Rajawali Pers:Jakarta.

Supiyata. 2019. Influence of Work Environment and Teaching Motivation on The Performance of Elementary School Teachers in Bandar Sribhawono District of East Lampung Regency. Thesis. Jakarta: Open University.

Susanti, Y. 2016. The Influence of Competence dan Commitmentof Professionalism toTeacher Performance (Research di JuniorState Commissariat 01 Ciamis). Ciamis: Galuh University.

Law of the Republic of IndonesiaNo. 14 thun2005 Tetang Teachers and Lecturers.

UNDP. UNDP Annual Report 2015 - 2019. [Online] Available: www.undp.org. [November 2, 2020].

Yumaroh, M. and Andriani, L. 2017. "The Influence of the Work Environment on Teacher Performance in SmK Negeri 10 Sungai Gelam District muaro JambiRegency". Scientific Journal of Economic Education. VOL. 1 (1), pp: 76 - 84.

Zickmund and Babin. 2013. Exploring Marketing Research. Salemba Four:South Jakarta. 